DOI: $10.22363 / 2312-9220-2021-26-4-641-648$

УДК 070

Research article / Научная статья

\title{
Ontology of Transgressive Social Media
}

\author{
Valentin N. Stepanov \\ International Academy of Business and New Technologies (MUBiNT), \\ 80 Sovetskaya St, Yaroslavl, 150003, Russian Federation \\ $\triangle$ vsrhetor2000@mail.ru
}

\begin{abstract}
This paper presents the T-Magic formula revealing ontology of social media which has become a transgressive form of media through its ability to build a digital community, sharing digital identity, and building a digital social capital, that prevails over offline human relations, and includes supporters and doubters estimated for their contact establishing function. Social media belongs to the so called culture of participation, and is considered as a versatile social phenomenon building a hybrid digital culture. Mutation seems to be a key characteristic of media in general and social media in particular. The consequences of the mutation' change shows pathway to a new ontology of digital communication, that of digital physics with a special focus on digital space and digital time, digital substance and digital energy. Transformation displays a technological turn in digital communication that reveals technological sources of digital energy. Transfiguration unveils the essence of digital substance, that of a social media sapience. Transgression outlines digital space and digital time, and is a means of overcoming "real" space and time by means of certain text units establishing bridges to connected personal or collective accounts or aggregate archives. The main function of the media text transgressiveness is to raise a so called publicity capital of a media subject initiating or releasing the post.
\end{abstract}

Keywords: social media, transformation, transfiguration, transgression, digital substance, digital energy, digital magic

Conflicts of interest. The author declares that there is no conflict of interest.

Article history: submitted: March 20, 2021; 2021; accepted: June 11, 2021.

For citation: Stepanov, V.N. (2021). Ontology of transgressive social media. RUDN Journal of Studies in Literature and Journalism, 26(4), 641-648. doi: 10.22363/2312-92202021-26-4-641-648

(C) Stepanov V.N., 2021

cc) (i) This work is licensed under a Creative Commons Attribution 4.0 International License

https://creativecommons.org/licenses/by/4.0/ 


\title{
Онтология трансгрессивных социальных медиа
}

\author{
В.Н. Степанов \\ Международная академия бизнеса и новых технологий (МУБиНТ), \\ Российская Федераџия, 150003, Ярославль, ул. Советская, д. 80 \\ vsrhetor2000@mail.ru
}

\begin{abstract}
Аннотация. В работе представлена формула «Т-магии», раскрывающая онтологию трансгрессивных социальных сетей через их способность формировать цифровые сообщества и цифровой социальный капитал, делиться цифровой идентичностью, которые надстраиваются над человеческими отношениями в реальности и учитывают многообразие ролей их субъектов. Социальные медиа формируют так называемую культуру участия и рассматриваются как сложное социальное явление, формирующее гибридную цифровую (медиа)культуру. Видоизменения (мутации) представляют собой основную характеристику современной медиасферы в общем и социальных сетей в частности. Последствия видоизменений помогают описать онтологическую природу цифровой коммуникации, в частности цифровой физики, цифрового пространства, цифрового времени, цифровой субстанции и цифровой энергии. Трансформации указывают на технологические изменения цифровой коммуникации и раскрывают технологические основы цифровой энергии. Трансфигурация помогает вскрыть суть цифровой субстанции (цифрового) медиасапиенса. Трансгрессия описывает цифровые пространство и время, преодолевающие «реальные» пространство и время с помощью специальных инструментов связи с другими аккаунтами и агрегаторами. Основная функция трансгрессивности медиатекста заключается в том, чтобы обеспечить прирост паблицитного капитала медиасубъекта, инициирующего пост.
\end{abstract}

Ключевые слова: социальные сети, трансформация, трансфигурация, трансгрессия, цифровая субстанция, цифровая энергия, цифровая магия

Заявление о конфликте интересов. Автор заявляет об отсутствии конфликта интересов.

История статьи: поступила в редакцию - 20 марта 2021 г.; принята к публикации - 10 июня 2021 г.

Для цитирования: Stepanov V.N. Ontology of transgressive social media // Вестник Российского университета дружбы народов. Серия: Литературоведение. Журналистика. 2021. T. 26. № 4. C. 641-648. doi: 10.22363/ 2312-9220-2021-26-4-641-648

\section{Introduction}

The term "social media" refers to an activity of a software tool or a platform. As a term, it is traditionally regarded as nebulous. The set of its usual attributes includes participation, openness, conversation, community, and connectivity.

Social media belongs to the "culture of participation" that "extends well beyond journalism", and is considered as "a broad social phenomenon" [1. P. 53]. In other words, social media is generally understood as something that "enables people to be more than simply members of an audience" [Ibid.]. 
Lipschultz examines social media's use in journalism, broadcasting, public relations, advertising and marketing, and emphasizes key concepts, best practices, data analyses, law and ethics on the platforms like Facebook, Instagram, LinkedIn, Snapchat, TikTok, Twitter, and YouTube [2].

The complex relationship between media, technology and social movements is engaged with contemporary debates in the field of social movements and new media.

Sophisticated digital practices and technologies exploit and capitalise on emotions, social media are used to exacerbate social conflicts. Emotions are being weaponised within mediatised political landscapes, enable affective information economies, and outline new frontiers of propaganda. The implications of recent innovations in information and communication technology for civic and political engagement in the digital age, and the impact of social media on citizens' propensity to get involved in political actions depict how online behaviour can act as a springboard into what might be called real-world politics.

\section{Social media and social capital: Sharing values}

Thorsen explains the relationship between journalists and their audiences by means of live blogging and social media, which also allows them to capitalize on the opportunities afforded by the immediacy, transparency and interactive nature of online communication [3].

The social and cultural implications of a digital, connected workforce are explored by Fast and Jansson [4]. Transmedia work refers to the rise of a new social condition that saturates many different types of work, with various outcomes. In some social groups, and in certain professions, according to Fast and Jansson, transmedia work is wholeheartedly embraced, while it is questioned and resisted elsewhere [4].

Kennedy offers definitions of sharing in digital culture, and the roles that the digital devices and the platforms play in these practices [5]. According to Kennedy, the relationship of sharing to privacy and control, the labored strategies and boundaries of reciprocation, and the relationships with the technologies mediate sharing practices [Ibid.].

The blockchain is a disruptive, revolutionary technology which is a means of sharing information and can be seen as a way to introduce the next level: sharing value [6]. The platforms encourage users to upload, share and respond to content, while the platforms themselves monetise the digital traces of this activity.

The central thesis of the theory of social capital "can be summed up in two words: relationships matter. By making connections with one another, and keeping them going over time, people are able to work together to achieve things that they either could not achieve by themselves, or could only achieve with great difficulty. People connect through a series of networks and they tend to share common values with other members of these networks; to the extent that these 
networks constitute a resource, they can be seen as forming a kind of capital» [7. P. 1]. According to Field, "Networks provide a basis for social cohesion because they enable people to cooperate with one another - and not just with people they know directly - for mutual advantage" [7. P. 12]. Thus, social capital is treated as a "relational construct" and even "a property of relationships" since "it can only provide access to resources where individuals have not only formed ties with others but have internalised the shared values of the group" [7. P. 139].

The shadow side of the "relational construct" embraces such "dark" aspects as misinformation, disinformation, and populism transmitted across countries, political systems, and media systems. The sphere of public communication is often attributed as polarised, anti-rational, post-fact, post-truth communication championed by populism.

Reed argues that making sense of digitised culture means looking past the glossy surface of techno gear to ask deeper questions about how we can utilize technology to create a more socially, politically and economically just world [8]. Mobile and social media, new platforms and devices have altered the way we interact with digital technologies in an allegedly 'post-truth' era.

\section{Anthropology of digitization: Digital humanities and immersive communication}

The distinction between online and offline realities is becoming more and more difficult to sustain. Digital tools and platforms for communication are progressively becoming commonplace, while the cultural conceptions that surround these technologies - immediacy, constant accessibility, availability are becoming increasingly mainstream and are called hybrid media culture.

The new cultural dynamics became evident and are seen as a result of digitisation, and the cultural changes are triggered by digitisation processes. For example, the ludification of culture reveals the significance of play and games in everyday practices of the digital era. The anthropology of digitisation enables the study of ethnography of digital infrastructures.

Digital humanities is seen as an established field with its own array of methodologies and projects operating at the intersections of media, culture, and practice, including access, praxis, social justice, design, interaction, interfaces, mediation, materiality, remediation, data, memory, making, programming, and hacking. For example, the issues pertaining to millennials and digital media ecology determine definite cultural, pedagogical, and political environments such heterogeneous generation populates.

Means of communication have changed immeasurably, and, according to $\mathrm{Li}$ [9], communication today has moved beyond the bi-directional mass communication of "the second media age" to ubiquitous, immersive communication in "the third media age". 


\section{The T-Magic of Social Media due to its three dimensional mutation}

Mutation seems to be a key characteristic of a transgressive media sphere with social media in its core. According to Li [9], media morphosis breaks through traditional spatial categories, and the evolutionary trends of media morphosis involve "coevolution and coexistence" and "anthropotropicness". The "anthropotropic" trend leads people to choose the most suitable things in order to survive. The results of the mutation show pathway to a new ontology of digital communication that of digital physics with a special focus on digital space and digital time, digital substance and digital energy. According to a more profane view, this is a way to a digital magic given in a metaphor displayed in the formula of T-Magic of Social Media, due to its three dimensional mutation.

The first $\mathrm{T}$ stands for transformation in a technological sense, it refers to a technological versatility in digital communication that reveals technological sources and means of digital energy.

Ellis and Tucker characterise the digital landscape as rapidly developing and consisting of the vast practices of digitisation and datafication, which constitute a digital age with its special concern to how emotion operates in, through, and with digital technologies [10].

According to transmediations, the processes of transfer and transformation occur when communicative acts in one medium are mediated again through another, thus, they are modified when transferred across multimodal media [11]. The broad variety of transmediations is viewed through four different "lenses" as follows: firstly, narrative transmediations; secondly, the spatial dynamics which is involved in media transformation; thirdly, new radical boundaries and media types in transmediality and its versatility; fourthly, the challenges involved in transmediating scientific data into the narrative format.

A rapid development and broad scope of Internet technologies determine the emergence of new digital genre classifications. According to Goroshko and Poljakova, "it is an extension of the offline genres theory but applied to the communicative space of the world wide web" [12. P. 119]. Thus, technological (web 1.0 - web 2.0 - web 3.0), hierarchical (hypergenre - genre - subgenre) and communicative-dynamic (conventional communication, convergence, hybridization, mutation) count as components of the proposed genre classification.

The information about the physical artefacts, digital content, performative interventions, practices and discursive expressions of affective sociality that ordinary citizens produce as they participate in public life is circulating across media and outlines a fast-evolving terrain known as citizen media which effect, aesthetic or socio-political change.

Emotion tokens given as emoji faces used in texts in social media provide digital communication with a new digital grammar, which contains special rules to, firstly, words and phrases substitution, secondly, phrase and period boarder 
marks, thirdly, initial and final signs of a communication unit that leads to a digital punctuation issues.

The second $\mathrm{T}$ stands for transfiguration, which unveils the essence of digital substance and determines a new view of a social media sapience.

Immersive communication reconstructs the relationship between media and the human being, which seems the "hottest and coolest" medium. Changes in the media space, the transformation of human living space and changes in the social functions of media bring changes to social relations and the ontology of human being. Immersive communication is seen as human-centered, according to Li [9], when everything is media, and humans are also a media form. Even the language of the virtual world as a whole depends on the linguistic hegemony of immersive media and follows the principle "moistens everything softly and silently".

The main characteristic of the digital substance is that a subject is transfigured into a navigator to be followed through the structure of the resulted unit, that of a post consisting of two parts including a presentation of and reaction towards the key message presented in the post. It also outlines the structure of cognitive basis of the subject's conscience, its emotional and intentional states with certain intentions to establish a dialogue, to support, or to doubt, to share a social value by clicking definite icons. The cognitive structure of a post navigation is aimed at provoking certain cognitive state in the public of emotional or intentional nature, provoking feelings, evoking thoughts, and sharing values.

Social media in ordinary people's wider patterns of media usage and everyday practices by Lomborg are further shown as communicative genres and $a$ cognitive category for making sense of the ordinary [13]. In everyday life, ordinary persons gain their status of public figures, and establish social media as a public sphere.

The development of digital technologies, for example, fasten the services for the tourists, who can use the digital technology to increase their working effectivity and productivity while enjoying the tourist destination. These people are usually freelance workers and called the digital nomads. Adam states that digital nomad as a term refers to those people who do not stay in a certain place for long time and work in long distance by using the Internet [14].

Global nomads is another name for the digital nomads who work independently, from their laptops, without a specific location as long as they have a good Wi-Fi connection. Long-distance work might be combined with a trip that includes "business and pleasure".

According to Vagena, digital nomads might be millennials 20 to 35 years old, tired of 9 am to $5 \mathrm{pm}$ working hours, who appreciate gaining new experiences, especially through travel [15]. They also might belong to generation $X$ between 35 and 50 years old, or Baby Boomers, who have turned 50 years old.

The third $\mathrm{T}$ stands for transgression and displays digital space and digital time navigation. The constructive units of a post characterized as a modular text which includes its measurement in two dimensions, that of width and height. 
Transgression is a means of overcoming space and time, and outlining digital space and digital time.

The revolution of media ontology and changes in social productivity, the ways and modes of communication evolve to "vanishing boundaries". According to Li [9], immersive communication is all-powerful, which means that boundaries between entertainment, work, and life vanish, and cloud computing integrates everything.

Transgressive potential of a post is determined and represented through insertion of heterogenic text units, or insets, such as different types of tagging (hashtags, hyperlinks, geolocation, geo tags) into a modular text. The main function of the media text transgressiveness is to raise a so called publicity capital of a media subject initiating or releasing the post.

The transgression marks in a post display means of digital geology. Firstly, it allows multiplying a message, typing it once, and presenting it several times by posting it in the accounts pointed in the insets or hyperlinks of collective or personal accounts, as well as public events.

Secondly, transgression through insets or hyperlinks determines a targeted addressee who gets a message just after having been mentioned.

Thirdly, geotagging leads to another option that of navigating and locating the presence of the author, showing its geolocation.

Fourthly, transgression outlines the emotional state of the author by displaying an emotional mark.

Finally, digital time is provided by hashtags which straightforward the messages to an aggregate community which is thematically connected to the original message to be laid therein forever. Technologically, one may also write a message and postpone its publishing for the time period needed.

\section{Conclusion}

Digital means of communication today has moved beyond the bi-directional mass communication of "the second media age" to ubiquitous immersive communication in "the third media age".

The T-Magic formula reveals the ontology of transgressive social media through its ability to build a digital community, share intent digital identity, and build a digital social capital that prevails over offline human relations and includes supporters and doubters esteemed for their contact establishing function.

Transformation displays a technological versatility in digital communication and reveals technological sources of digital energy. Transfiguration unveils the essence of digital substance, that of a social media sapience. Transgression outlines digital space and digital time, and is a means of overcoming "real" space and time by means of certain text units establishing bridges to connected personal or collective accounts or aggregate archives. 


\section{References / Библиографический список}

[1] Heinonen, A. (2011). The Journalist's Relationship with Users: New Dimensions to Conventional Roles. Participatory Journalism: Guarding Open Gates at Online Newspapers (pp. 34-55). Chichester: Wiley-Blackwell.

[2] Lipschultz, J.H. (2020). Social Media Communication: Concepts, Practices, Data, Law and Ethics. Abingdon, UK and New York: Routledge.

[3] Thorsen, E. (2013). Live Blogging and Social Media Curation: Challenges and Opportunities for Journalism. Journalism: New Challenges (pp. 123-145). England: CJCR: Centre for Journalism \& Communication Research, Bournemouth University.

[4] Fast, K., \& Jansson, A. (2019). Transmedia Work: Privilege and Precariousness in Digital Modernity. Abingdon, UK and New York: Routledge.

[5] Kennedy, J. (2019). Digital Media, Sharing and Everyday Life. Abingdon, UK and New York: Routledge.

[6] Blockchain and Web 3.0: Social, Economic, and Technological Challenges. (2019). Abingdon, UK and New York: Routledge.

[7] Field, J. (2008). Social Capital. Abingdon, UK and New York: Routledge.

[8] Reed, T.V. (2019). Digitized Lives: Culture, Power and Social Change in the Internet Era. Abingdon, UK and New York: Routledge.

[9] Li, Q. (2020). Immersive Communication: The Communication Paradigm of the Third Media Age. Abingdon, UK and New York: Routledge.

[10] Ellis, D., \& Tucker, I. (2020). Emotion in the Digital Age: Technologies, Data and Psychosocial Life. Abingdon, UK and New York: Routledge.

[11] Transmediations: Communication Across Media Borders. (2019). Abingdon, UK and New York: Routledge.

[12] Goroshko, O.I., \& Poljakova, T.L. (2015). The construction of genre typology of the social media. In Speech Genres, 2(12), 119-127. doi: 10.18500/2311-0740-2015-2-12119-127 (In Russ.)

Горошко Е.И., Полякова Т.Л. К построению типологии жанров социальных медий // Жанры речи. 2015. № 2 (12). С. 119-127. doi: 10.18500/2311-0740-2015-2-12-119127

[13] Lomborg, S. (2019). Social Media, Social Genres: Making Sense of the Ordinary. Abingdon, UK and New York: Routledge.

[14] Adam, R.L. (2018). 8 Ways to Make Money As a Digital Nomad: With the right skills and a good internet connection, you can make a living anywhere. Retrieved May 02, 2021, from https://www.entrepreneur.com/article/307252

[15] Vagena, A. (2021). Digital Nomads and Tourism Industry. Academia Letters, Article 765. doi: 10.20935/AL765.

\section{Bio note:}

Valentin N. Stepanov, Ph. D. (Doctor of Philology), Professor, Merited Educator of Tertiary Education of the Russian Federation, Head of Dpt. of Mass Communication of International University of Business and New Technologies (MUBiNT). ORCID: 0000-000181-98-2517; e-mail: stepanov@mubint.ru

\section{Сведения об авторе:}

Степанов Валентин Николаевич, доктор филологических наук, профессор, заслуженный работник высшей школы Российской Федерации, заведующий кафедрой массовых коммуникаций ООВО (частное учреждение) «Международная академия бизнеса и новых технологий (МУБиНТ)». ORCID: 0000-0001-81-98-2517; e-mail: stepanov@ mubint.ru 